\title{
Officer Professional Education in the Canadian Forces and the Rowley Report, 1969
}

\section{Colonel (retired) Randall Wakelam}

In the late 1960s the Canadian Military was experiencing a peacetime upheaval. The three previously independent Services were being amalgamated - unified - by political direction. This meant that previously independent processes, including professional education, had to be rethought and reorganized to fit the new single-force philosophy. Under the leadership of a battlefield commander, Major-General Roger Rowley, a small team set out to devise a radical concept for academic and professional education that would provide officers with a coherent suite of learning programs spanning their careers, all provided for by an integrated single military-civilian teaching engine. The plan immediately met resistance from pre-existing organizations and, harried by organizational reductions, faded from the scene, even as the value of enhanced education was receiving general support. In 2002, with a renewed focus on intellectual agility, the concept was resurrected with the establishment of the Canadian Defence Academy.

À la fin des années 1960, en pleine période de paix, les militaires canadiens vécurent un remaniement. Les trois branches des forces armées, précédemment indépendantes, furent intégrées, réunifiées, par les autorités politiques. Cela signifiait que des secteurs d'activités autrefois séparés, dont la formation professionnelle, devaient être repensés et réorganisés dans l’optique d'une force armée unifiée. Sous la gouverne d'un commandant de l'armée de terre, le Major général Roger Rowley, une petite équipe chercha à mettre au point un tout nouveau concept d'éducation académique et professionnelle qui fournirait aux officiers un ensemble logique de programmes d'apprentissages durant leur carrière, tous ces programmes étant fournis par un appareil éducatif militaro-civil unique intégré. Le projet rencontra la résistance immédiate des organisations antérieures ; miné par des compressions structurelles, il disparut alors même que la nécessité d’une éducation plus relevée recevait un appui généralisé. En 2002, les aptitudes intellectuelles étant de nouveau au cœur des préoccupations, le concept fut ressuscité à travers l'établissement de l’Académie de la Défense canadienne.

On 16 October 1967 General Jean Victor Allard, Chief of the Defence Staff (CDS), assigned a demanding task to his newly appointed Chair of the Officer Development Board (ODB), Major-General Roger Rowley. He wanted Rowley and 
his team to sort out officer education for the Canadian Forces. ${ }^{1}$ As part of its mandate the ODB was to plan for and make "recommendations on the most effective manner in which the development of our officers can be co-ordinated, and to define the responsibilities of the agency best suited to exercise control over the academies, colleges and other institutions responsible for this development."2 Other functions of the Board included defining officer professional development requirements and teaching organizations to cover the full gambit of needs of officer cadets through to general and admirals. As well, the team was to prepare transition plans and identify resource requirements.

Rowley's response, presented in some 500 pages of the formal Report of the Officer Development Board, was endorsed by Allard on 3 March 1969. The document laid out a scheme for the rationale, educational content, courses of study, transition to, and governance of a Canadian Forces officer development system. At the heart of it was a coherent suite of academic and professional development activities conducted by a military university, the Canadian Defence Education Centre (CDEC), with an integrated military-civilian faculty. ${ }^{3}$

Rowley had made no secret that it would take a full decade before the impact of the recommendations would result in a fully effective officer professional development system, ${ }^{4}$ but throughout the preparation of the study Allard had seemed well satisfied with the concept. ${ }^{5}$ Rowley's CDEC would replace the existing military and staff colleges ${ }^{6}$ and would provide officers with all their education and professional development needs from baccalaureate degrees to interdepartmental national

1 Canada, Department of National Defence, Report of the Officer Development Board, Vol. 1 (Ottawa: DND, 1969), iii. Subsequently referred to as the ODB Report, Vols. 1, 2, or 3. The Chair of the ODB was Major-General Roger Rowley.

2 DB Report, Vol. 2: 330; Annex A, p 1.

3 ODB Report, Vol. 1: iv.

4 ODB Report, Vol. 2: 330, par. 17..

5 Interview with Lieutenant-Colonel (LCol.) (retd.) Larry Motiuk, Jan. 2001. According to Motiuk, a member of the ODB, when Rowley's briefers took the plan before Allard he stopped them about ten minutes into the presentation, exclaiming that finally someone had listened to what he wanted.

6 Military colleges, also known as service colleges, were the military universities that prepared new officers for entry into the service while at the same time granting them a degree. Staff colleges gave mid-career officers advanced professional education in command and leadership and military operations and administration in preparation for higher rank and responsibilities. Staff colleges were not unlike Master of Business Administration programs. 
security courses. ${ }^{7}$ The Centre would be unique in how it dealt with pre- and post-commissioning (pre- and in-service) officer education. Unlike other nations with their autonomous navy, army, and air force cadet, staff, and war colleges, the CDEC's two-star commander would report directly to Allard and would be accountable for all officer education policy, plans, and programs. $^{8}$ It would therefore be a line organization, with a formally appointed commander who had both the responsibility to the profession to provide the needed programs, and the authority and resources to get the job done. This commander would discharge a function that in Canada had previously been managed by individual service staffs and lesser commanders.

The context of Rowley's study was the Cold War world of the 1960s. As well, the Canadian military was in the throes of politically mandated Integration and Unification that would lead to the creation of a single unified military service on 1 February 1968. Officer education - alternatively called professional development - was an important instrument in preparing military professionals for the uncertainties of the Cold War reality, not just in Canada but in the U.S. as well. There the Services gave new officers undergraduate degrees as an intellectual foundation for future development, while the highest levels of professional education were designed to give officers the competencies needed to advise government on matters of national security. ${ }^{9}$ Both nations' systems were built on long-standing European models such as the German Kriegsacademie, the French cadet schools, and the British Imperial Defence College. These countries and others in Europe operated systems that, as described by the Report's annexes, embodied the three levels of

7 ODB Report, Vol 2: 330. Describing the Headquarters CDEC, the Report said that "the organization of the headquarters must fit the task, not vice versa, and that striving for a 'pretty' structure without regard for its precise use, is futile.”

8 ODB Report, Vol 2: 321-37. Chapter 37, "Design of the Organization to Command and Manage the New Officer Development System," provided a complete discussion of the proposed command and accountability functions as well as the functions to be assigned to HQ CDEC. Discussions about the importance of governance are to be found throughout the report's three volumes.

9 John W. Masland and Laurence I. Radway, Soldiers and Scholars: Military Education and National Policy (Princeton: Princeton University Press, 1957). The authors, commissioned to review and comment on the adequacy of U.S. officer development programs, found that while there existed some difficulties the overall blending of courses produced professionals with both firm professional abilities and a good grasp of their personal roles and functions. In their preface they let readers know that their investigations had revealed an imperfect system, but one not dissimilar to those found in the U.S. higher education system in general (xi). 
officer education. ${ }^{10}$ Implicitly, and often explicitly, these national systems indicated that the profession of arms required a unique professional development system that would give personnel the necessary skills and knowledge to discharge their service responsibilities effectively. In reviewing both the strategic context and the professional development philosophies of other nations, Rowley concluded that higher levels of education were the norm given the increasing complexity of military operations and defence issues. ${ }^{11}$

The civilian professions have also had their own unique but not dissimilar systems of preparing aspirants. In Professional Gentlemen, which examines professions and professional education in nineteenth-century Ontario, R.D. Gidney and W.P.J. Millar argue that professional education focuses not just on the "learning about" but also on the fundamentally important "learning how."12 Gidney and Millar explore how the three traditional professions - divinity, medicine and law - recognized that this technical proficiency had to be accompanied by a liberal education, which remained "the touchstone of the educated man: it constituted a training in character and culture, the necessary prerequisite to framing technical expertise within 'scientia'..."13 Scientia - knowledge - was thus a fundamental component of the individual's formation, giving the professional the ability to examine issues within a wider intellectual framework, while at the same time conferring a certain social status both on the individual and the profession. Recently, similar conclusions have been reached by Eliot Freidson in Professionalism: The Third Logic, in which he argues that all training, whether for craft, technical, or professional work, involves some degree of vocational training; but professions benefit from the broadening experience normally associated with a university milieu and approach to learning. ${ }^{14}$

While these works do not consider the question of military professionalism in any depth, other researchers have pursued that

\footnotetext{
10 ODB Report, Vol. 1: Annexes H-L.

11 Ibid., Annex J, 8.

12 R.D. Gidney and W.P.J. Millar, Professional Gentlemen: The Professions in Nineteenth-Century Ontario (Toronto: University of Toronto Press, 1994), 152. See also Samuel Haber, The Quest for Authority and Honor in the American Professions, 17501900 (Chicago: University of Chicago Press, 1991).

13 Gidney and Millar, Professional Gentlemen, 355.

14 Eliot Freidson, Professionalism: The Third Logic (Cambridge: Polity, 2001), 84, 90, 121 .
} 
topic. For example, in The Soldier and the State, Samuel Huntington, a Harvard academic and recently the author of The Clash of Civilizations, argued that an officer's associated duties included preparing the force, planning its mission, and directing its actions. An officer's skill was neither "craft" nor "art." "It is instead an extraordinarily complex intellectual skill requiring comprehensive study and training." In Huntington's view, acquiring this intellect required about one third of an officer's career. Mastery came not simply through "learning existing techniques. [Professional competency] is in a continuous process of development, and it is necessary for the officer to understand this development and to be aware of its main tendencies and trends." Even this was not enough, for Huntington posited that the officer must be in tune with the culture in which he operated. This required an understanding of society, of the characteristics of other professions, and of human beings themselves. ${ }^{15}$ Huntington's military professional thus needed to acquire and maintain a broad and complex expertise in order to "manage violence" on behalf of society and the state.

I begin this study with a brief review of the main elements of post-commissioning professional development in Canada's three Services prior to unification. I then turn to the Rowley Report and highlight some of its seminal recommendations. One cannot help but be impressed with the scope, depth, and decisiveness of this document. I also look at the institutional politics that led to the abandonment of much of the structure that was intended to act as an educational anchor during changes in administrations and defence policies, and show how some of the professional programs survived, but how much of the coordination that was necessary did not come into being. I conclude by jumping ahead some twenty-five years to a point where the Canadian Forces has again found itself in transition. Here, the end of the Cold War and several examples of flawed performance have precipitated a series of reviews of education parameters. The recent solutions to these challenges have seen what is arguably a re-creation of Rowley's vision.

15 Samuel P. Huntington, The Soldier and the State: The Theory and Politics of CivilMilitary Relations (Cambridge, Mass.: Belknap (Harvard) Press, 1957), 11-14. 
PRIOR TO INTEGRATION and unification the three Services each carried out professional development in their own fashion. ${ }^{16}$ Each Service conducted its own training in technical and tactical procedures, using a variety of schools and establishments. The officer cadet or military colleges were separate from the "staff training colleges," which included the Canadian Army and Royal Canadian Air Force (RCAF) staff colleges. At the staff college level both the Army and the Air Force concentrated on the employment of large forces and on the strategic settings in which forces were used. The Navy sent a small number of students to the Royal Navy Staff College and also to the RCAF program, but did not operate its own institution.

From the end of the Second World War until 1967, the Army conducted its own two-year Canadian Army Staff College at Fort Frontenac in Kingston. The course was reduced to one year in length at that point, but even the cut-down version offered an impressive scope. Describing the program in the College's journal, Snowy Owl, the Commandant, Brigadier General W.A. Milroy, stated that students would graduate with a "thorough understanding of the principles and techniques" of land operations, including "specialized staff skills, a knowledge of military management, and the functions of the staff." The latter included logical and critical thinking as well as communications skills. Graduates would also gain a grasp of national security issues in their broadest sense. Finally, the course would include ample opportunity for the practice of staff skills in solving "typical command and staff problems encountered in war and situations short of war throughout the world, with emphasis on the divisional level and below."17 In sum, the Army conducted a program clearly oriented to developing staff officers for employment with large battlefield organizations while at the same time offering a glimpse at the geo-political roots of defence and a grounding in critical thinking.

The Army published a pair of articles in the Canadian Army Journal in 1963 that offered some insight into the courses of its sister services. The articles, according to its editor, (then) Colonel Milroy, were in response to the growing interchange of

16 Their systems were described briefly each year in Dominion Bureau of Statistics (DBS), Canada Year Book. See for example DBS, Canada Year Book, 1961, 1117-18. 17 Brigadier General W.A. Milroy, DSO, CD, “The Course,” Snowy Owl 4, 2 (196768): 2-3. 
officers undergoing professional development as a result of the integration of the three Services. For example, the Air Force contingent on the Army staff course had grown from two officers to ten, while the Navy increased the number of participants from one to two. ${ }^{18}$ The articles were thus intended to tell Army officers more about professional education in the other services; more significantly, they also served to highlight the differences in professional development philosophies between the three. The article on the "training" of naval officers dealt uniquely with junior officer training. Written by the junior-ranked Staff Officer, Training Publications from the Directorate of Naval Training, the piece concentrated on the complexities of life at sea for a new member of the Naval Service. The focus of the article and of the training was on how one became a competent junior naval officer ready to move on from general employment to specific advanced duties within a ship's company. ${ }^{19}$ Those aware that the Navy did in fact send senior officers to attend the Royal Navy Staff College in England and the Royal Canadian Air Force program in Toronto might perhaps have been surprised or even concerned that the article made no mention of this higher level of professional development.

A prior issue of the Canadian Army Journal had included a similar piece on "professional education" in the RCAF. ${ }^{20}$ The contrast between the Navy's emphasis on job-related training and the Air Force's focus on broad education was immediately evident to someone comparing the two articles. The Air Force approach concentrated on the career development that took place after the officer was technically competent for a particular "trade specialty” such as pilot, supply officer, or air traffic controller. Their professional education system provided officers with the cognitive skills and in-depth knowledge necessary to make reasoned decisions and to function in large multi-dimensional organizations where co-ordinating the efforts of peers and subordinates would be a central function. Overall, the Air Force content was not much different from that of the Army, but there

18 Interview with Lieutenant-General (LGen.) (retd.) W.A. Milroy, June 2002.

19 Lt. H.R. Percy, "Training the Navy’s Officers," Canadian Army Journal 17, 3 (1963): 57-69.

20 Wing Commander G.K. Murray, "Professional Education in the RCAF," Canadian Army Journal 17, 2 (1963): 47-55; reprinted from an article in the RCAF magazine Roundel 14, 10 (Dec. 1962): 8-13. There is no indication in Roundel as to Murray's background or position, although it is likely that he was either on the staff or had served on the staff at the Air Force College. 
was a significantly different approach to the management of professional development.

A key theme of the Air Force article was the fundamental importance of the control and co-ordination of education programs. Having recognized the value of professional education, in the 1940s and 50s the Air Force had established a number of courses and programs, but these had not been coordinated. The article's author, Wing Commander Murray, commented that "because [the delivering] agencies developed more or less independently there was a danger that such education was being carried out in a piecemeal fashion. By 1958 it became clear that to ensure proper span of control and effective policy direction, one single agency was required to provide unified control in the field of professional education."21

These few words described what had been a fairly lengthy and perhaps not too harmonious process of reining-in the Air Force's professional education programs. In June 1958 the RCAF Staff College Board of Governors had recommended the establishment of a committee "to review professional education in the RCAF." 22 On 29 September such a panel was authorized by the Vice-Chief of the Air Staff (VCAS), who charged them to examine "the implications of coordinating the existing agencies of professional education in the RCAF." ${ }^{23}$ Reporting back within sixty days the committee stated that

a professional education process can be composed of a number of courses, examinations, and other instructional agencies. But as all contribute to a single aim and exist to fulfill this aim, the coordination between all agencies is essential. The best coordination would be provided by having all agencies of education controlled by a commander with that responsibility alone. ${ }^{24}$

Expressing this notion more forcefully in its conclusion, the committee, wrote that "the process of educating is...done piecemeal and cannot be anything but inefficient, uneconomical,

21 Murray, "Professional Education," Roundel, 9.

22 Department of National Defence, Directorate of History and Heritage (DHH), Officer Development Board (ODB) Papers, "C470-1 (CTrain), A Report on RCAF Professional Education prepared for the Vice-Chief of the Air Staff by an Ad Hoc Committee November 1958," 1.

23 Ibid.

24 Ibid., 6. 
and inadequate.”25 The proposed solution for this situation was the creation of an RCAF Air University that would ensure "unified control and continuous coordination" and hence the "most suitable and efficient means of RCAF professional education today and in the future."26

In June 1959 the Vice Chief convened another senior level conference at the RCAF Staff College in Toronto to review the process of establishing what was by then being called the Air Force College. ${ }^{27}$ The Vice Chief opened the session by stating that the Air Council, the RCAF's senior policy body, had approved the new college, but that it had "not been definite" on governance arrangements. He was therefore asking for opinions on whether the College should come under the Air-OfficerCommanding Training Command or if it should report directly to Air Force HQ. Air Vice Marshal Bryan, commander of Training Command, supported the first option, but the Chief of Training at AFHQ, Air Commodore Lister, "found it difficult to see how [Training Command] could be expected effectively to set the standards and, at the same time, supervise the training and assess the results." The minutes record that the Vice Chief closed the discussion on the command and control of the Air College by stating that it had not been intended to come to any firm decisions, but merely to explore the matter. ${ }^{28}$ Clearly, however, there had been a desire to find a means of grouping professional education under one organization, and the fact that senior commanders and staff could not find a consensus on how to proceed is indicative of the complexity and uniqueness of the question.

By 1961 an umbrella structure, the Air Force College, had been activated, and its staff members were busy trying to define the optimum structure to provide for a Staff College, Staff School, planning and research activities, and, eventually, an extension program. A small team produced a comprehensive study; its comments on planning and co-ordination of curriculum reflect the nature of the challenge:

Ibid., 11.

Ibid., 15.

DHH, ODB Papers, "C9-03 (RTH) Minutes of a Conference held at RCAF Staff College at 0900 hours 12 Jun 59 to Review the Function of the Staff College,” 3.

28 Ibid., 3-4. 
The activities of defining the basic professional syllabus, of developing study requirements for individual courses, and for planning changes to the education system are all intimately related to research and study of the professional field of knowledge. Yet these activities are all coordinating activities in the sense that they determine the relationship of one course to another within the education system, and that they show a need for change or the establishment of new courses. Thus it seems unwise to separate coordination or education system planning as distinct administrative functions which can be performed by administrative methods divorced from a knowledge of the syllabus and a close familiarity with the instructional methods available. ${ }^{29}$

Given the complex interconnection between program requirements and course content, the study recommended that the Air Force College headquarters should be responsible for a variety of tasks, including "developing RCAF educational concepts, policies, plans and programs; developing Air Force College operating policies; helping develop, and approving, program outlines; and carrying out advanced syllabus and doctrine research." 30 At the same time detailed course development and syllabus planning would be the tasks of the Staff College and Staff School. In short, the study recommended that while the headquarters would establish broad learning goals and the policies and procedures needed for achieving them, the daily planning and delivery of the curricula should fall on those organizations charged with those tasks. This philosophy of centralized control, still not perfected by the Air Force, was to have a major influence in defining officer education for the Canadian Forces.

The newly legislated Canadian Forces of the late 1960s was thus a force with three distinct officer professional development systems that, to a significant degree, lacked a common philosophy and process. Between them they covered a spectrum from practical training to broad conceptualization of defence and security issues. There was a requirement to harmonize and economize, while at the same time ensuring effective, coordinated professional development. This was Rowley’s task.

29 DHH, ODB Papers, "2-01(RJG) A Report on Air Force College Organization Prepared for the Commandant by a Working Group,” 20 Mar., 1961, 4.

30 Ibid., 12. 
ACCORDING TO A SENIOR member of the Board, Rowley gave his team carte-blanche so that they could develop a solution to the problem based on a complete review of requirements and options. ${ }^{31}$ Rowley's own background no doubt contributed to his desire for a full investigation. A graduate of Dalhousie University, he had joined a militia regiment, the Cameron Highlanders of Ottawa, in his hometown in 1933. Mobilized during the war, he served as a Commandant of the Canadian Army Battle School in the UK and Commanding officer of the Stormont, Dundas, and Glengarry Highlanders in combat in France and Germany. After the war Rowley attended both the British Army Staff College and the British Imperial Defence College, in 1947 and 1953 respectively. He commanded 2 Canadian Infantry Brigade in Germany and was Commandant of the Canadian Army Command and Staff College from 1958 to 1962. ${ }^{32}$ Now in his last appointment before mandatory retirement at age 55, Rowley allowed his staff the "freedom to adventure" and they developed a fairly radical alternative to the patchwork of schools and courses then in operation. In place of the existing matrices they proposed a single "officer factory," and a small number of subsidiaries, which would offer a series of co-ordinated education and professional development programs and courses designed to take an officer from enrolment through to employment at the most senior ranks.

Rowley began by defining an officer and an officer corps in a Canadian context; then he defined a professional development system for them. Coming up with acceptable definitions of the military professional was undoubtedly challenging for there was considerable debate going on, particularly in the U.S., on this very issue. $^{33}$ Adding the particular Canadian dimensions of

\footnotetext{
31 Interview with LCol. (retd.) L. Motiuk, Feb. 2001.

32 The Canadian Who's Who Volume XII, 1970-1972, 555.

33 Works by authors such as Huntington, The Soldier and the State, and Charles Moskos, The American Enlisted Man: The Rank and File in Today's Military (New York: Russell Sage Foundation, 1970), had caused Americans and American officers to speculate about the profession. The experience of Vietnam had convinced others, such as U.S. Navy Admiral Stanfield Turner, President of the Naval War College, to link professional difficulties to the question of professional education, as he did in a 1972 address to incoming students: "Why have we eroded our credibility? One cause is that higher military education has come to substitute prolonged briefings for rigorous intellectual development. This is because almost every aspect of our society today has some impact on national security. Our war colleges have succumbed to the temptation to add piecemeal to their curricula in a fruitless quest to cover everything of relevance. Another sample of the ineffectiveness of our military educational system is our increasing reliance on civilians and on 'think tanks' to do our thinking for us. Do not misunderstand.
} 
small middle power, peacekeeping, and unification of the services served to complicate the task further. After extensive research and synthesis the Board developed a model of officer qualities that included:

- the soldierly virtues (classic qualities including loyalty, honour and courage; in short, a professional ethos)

- command ability (the ability to command groups of subordinates commensurate with rank)

- branch and specialty skill (infantry, aerospace engineer, logistician, etc)

- list competence (the ability to employ large forces for sea, land, air, or support operations; at this level officers would not be expected to be expert in other than their own 'list')

- military expertise (knowledge of the capabilities of armed forces, both domestic and foreign, and an ability to provide strategic level military advice to government)

- intellectual capability (native intelligence for use in grasping concepts, reasoning logically, and solving problems)

- $\quad$ executive ability (capacity to deal with problems and decisions that "defy solution")

- military-executive ability (the context in which the officer will apply his executive ability and military expertise and give his advice to government)

Rowley saw these qualities interacting to varying degrees at different points in an officer's career. For example, specialty skills, such as commanding an infantry platoon, became less important as an officer advanced in rank, while at the same time military-executive ability, at its highest level the ability to advise government on matters of national security, would be vital for a general or admiral. ${ }^{34}$ Whether these qualities were unique to the

These people have done outstanding work for us. We will very much need their help and stimulation in the future. We must, however, be able to produce military men who are a match for the best of the civilian strategists, or we will abdicate control of our profession. Moreover, our profession can only retain its vitality so long as we ourselves are pushing the frontiers of knowledge in our field." See "Convocation Address," Naval War College Review (Nov.-Dec. 1972): 2-10; reprinted, ibid. (Winter 1998): 72-80.

34 ODB Report, Vol 1: 39-41. 
Canadian military or to militaries generally, or whether they were more broadly applicable to all professions (with reference to the military replaced by other professional competencies) is certainly an intriguing question. What appears reasonably certain is that Rowley had found a way to summarize inclusively the qualities common to all officers in the Canadian context.

From this identification of officer qualities the Board was then able to derive a series of "guiding precepts" for an officer development system. Among other things, the new system was to:

- prepare officers to contribute to a Canadian national strategy

- impart the Canadian military ethic

- remain in consonance with scientific, technological, sociological, economic, educational, military, and strategic changes

- accept the baccalaureate as the basic educational level for entry to the officer corps

- ensure that courses taught at the military college are relevant to the technical and operational requirements of the military

- provide the appropriate professional-development course material at the right stage to assist the officer in the orderly development of the qualities demanded of him at succeeding levels

- encourage original research on military matters within the officer corps

- $\quad$ permit no degradation of operational effectiveness

To attain these aims the system must, in addition, be efficiently organized, well integrated and effectively commanded. ${ }^{35}$

Rather than perpetuate the web of existing organizations that reported directly to the national headquarters, the ODB proposed that one organization, the Canadian Defence Education Centre (CDEC), be established to develop policy, make plans, and conduct programs and courses on behalf of the military. At the policy and planning level the CDEC headquarters would analyze 
Canadian Forces' needs and develop policies and plans to provide the necessary education and professional development to meet those needs. At the operating level the CDEC would in effect be a university with two colleges: the Canadian Defence College (CDC),offering in-service professional development to commissioned officers, and the Canadian Military College (CMC), providing undergraduate and graduate education.

This university would have the ability to design and implement education and professional development programs derived from the competencies defined by the national headquarters. Having grouped the resources of the former cadet and staff colleges into one entity, all located at Rockcliffe in Ottawa's east end, CDEC would have the institutional depth and flexibility to adjust to new tasks without significant changes to organization. The programs to be conducted by CDEC would include undergraduate degrees, graduate degrees, a Junior Staff Course, a Junior Command and Staff Course (Land), academic extension courses, a preparatory (pre-Command and Staff Course) studies program, a Command and Staff Course, and an Advanced Military Staff Course. CDEC would also operate a library for use by all students and faculty and a wargaming facility for use by Defence College courses. ${ }^{36}$

There were to be two other major delivery agencies for officer professional development. The first organization was the National Security Course (NSC), which would replace the National Defence College (a body operated directly by Ottawa, offering a ten-month program of national security studies for senior military, government, and private-sector executives), but have roughly the same mandate. Rowley saw the NSC as a pangovernment program, dealing, as did its predecessor, with the overall security of the nation and not just defence matters. A Centre for Security Studies would be created to conduct research both in support of the NSC as well as the strategic studies components of other courses and programs. ${ }^{37}$ The second delivery organization, described only briefly in the Report, was the Canadian Military Academy (CMA). While not depicted in organization charts it was described as the facility that would deal with the Officer Candidate Training Plan - a program for

36 These courses are summarized briefly in Vol. 1 of the ODB Report, 97-104, and in considerably more detail in Vol. 2.

37 ODB Report, Vol. 2: 265-70. 
non-degreed officer production that would eventually be phased out. $^{38}$

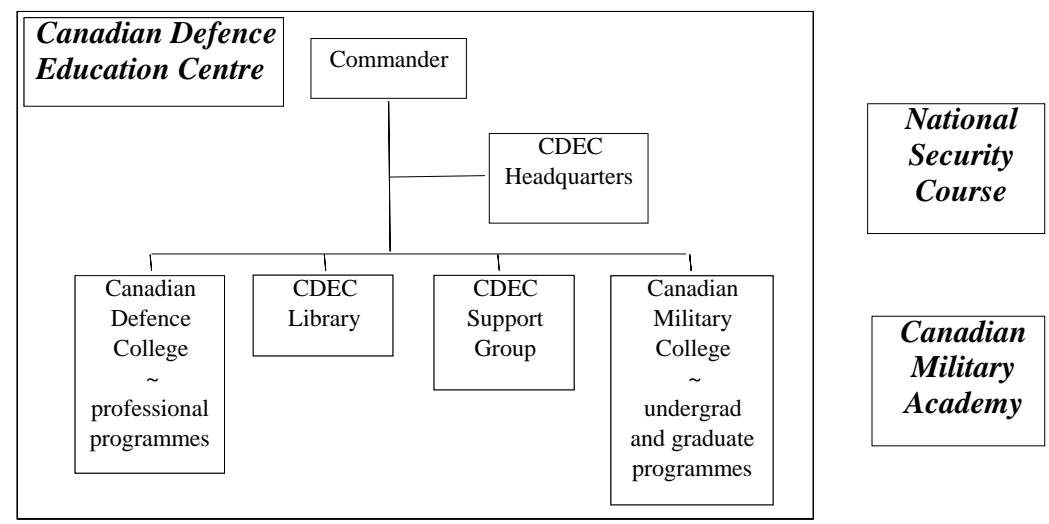

Within the CDEC the Canadian Military College would offer a range of arts, sciences, and engineering degrees based on service needs. The college would operate twelve months a year to maximize efficiency. Year-round classes would also allow one- third of the student body to undergo military training at all times; thus all students would benefit from having been in the field during all seasons of the year by the time they were ready to join their first unit. ${ }^{39}$ The proposal looked not unlike the University of Waterloo's now-renowned and widely adopted cooperative education program.

Once commissioned, an officer entered a normalized professional development path that would take him through a series of courses based on rank. Here perhaps it should be mentioned that in the military lexicon a course can be as short as a two-day defensive driving qualification or as long as the ten-

38 Ibid., 172-74, 177. Indeed there were many officer production mechanisms that did not require attendance at CDEC programs but that would still be controlled by the Centre. These included the Commissioning from the Ranks Plan; the Direct Entry Officer Plan (for individuals joining the military after university); the University Training Plan (Men) (for NCOs gaining their commissions via a university program); and the Regular Officer Training Plan (usually associated with individuals attending a civilian university immediately after high school, but actually including CMC students).

39 Ibid., 87-90. 
month Command and Staff Course with over, 1,000 curriculum hours. The courses, all taught at the CDC (except the NSC), can be summarized as follows:

- Junior Staff Course - “at captain level to teach unified junior military staff procedures of a general nature"

- Junior Command and Staff Course (Land) - "[at captain level] for land force officers to teach operational staff procedures”

- Command and Staff Course - "at the major level basically to impart list [sea, land or air] competence”

- Advanced Military Studies Course - "at the lieutenant-colonel level to broaden list competence and emphasize military expertise, particularly through the study of high-level military operations"

- National Security Course - "to develop to the fullest extent possible an awareness of the national and international environment and thus to impart militaryexecutive ability"40

While these courses would impart knowledge and to some extent skills, "the policy of making the courses sufficiently demanding to help build intellectual ability and executive ability is recognized. Emphasis on the military virtues including leadership is recognized throughout." ${ }^{\prime 1}$ In other words the professional development process would emphasize not just skills and knowledge, but also the cultivation of logical and ethical thought. Additionally, post-commissioning learning "must [include] a post-graduate programme...[fulfilling service needs for special and non-specialist officers] with a fairly extensive understanding in one or other of the many disciplines that are part of the corpus of knowledge that the military profession embraces." 42 Together the content, intellectual rigour, and ethical context would contribute to the formation of military professionals.

If one thought of the Education Centre's mandate in terms of the provision of post-secondary academic and professional education suited for the military needs of the 1970s, then the

Ibid., Vol. 1: 98.

Ibid.

Ibid., 99. 
"product line" covered all requirements. There was a wide range of undergraduate options and a variety of post-graduate qualifications tailored to Service requirements; together these provided a strong intellectual development for the officer corps. As well, there was a full suite of professional "management" courses that would ensure that individuals were well prepared for the challenges of rank and appointment as they advanced through their careers. What appeared to make Rowley's approach superior to the patchwork of single-service programs was the single and co-ordinated strategy that CDEC would take on behalf of the entire Canadian Forces. While there was no attempt to conduct tightly constrained prescriptive professional education where one size would be forced on all, the system would ensure that officers progressed through a common development system regardless of their occupation or branch of service.

DESPITE ITS PROFESSIONAL development mandate the Canadian Defence Education Centre was still a military organization in terms of structure and hierarchy. The Commander, a two-star line officer, was responsible to the Chief of Defence Staff. In this, the Officer Development Board sought to break away from previous structures where professional education organizations were buried within personnel or training staffs and instead institute a framework akin to those in most major nations where professional development was considered essential to sustaining the Service. ${ }^{43}$ Within the CDEC the Commander would direct the two colleges, which would each have a one-star commandant. The CDEC would include a robust headquarters tailored to the task of organizing and operating the officer professional development system for the Canadian Forces. ${ }^{44}$

Recognizing that this military organization would function much like a civilian university, the proposed control elements of CDEC were intended to replicate a post-secondary structure. The Board recommended the creation of a Deputy for Education, the post to be filled by a senior academic from one of the three former military colleges (Royal Military College in Kingston, Royal Roads Military College in Victoria, and Collège Militaire 
Royale de St-Jean, just south of Montreal). ${ }^{45}$ As well, because the CDEC would offer undergraduate and graduate degrees, it was planned to use RMC's provincially granted charter and to incorporate the RMC senate structure, but with amendments to its jurisdiction to include the Defence College, Military College, and Military Academy. ${ }^{46}$

In order to deal with professional needs of the academic staff, such as promotion and tenure, a Faculty Review Committee was proposed. It would operate under the auspices of the Deputy Minister of National Defence (with responsibility for all public servants within the Department) and would, like the new senate, expand the previous military colleges' faculty review functions to include academic staff working at the $\mathrm{CMC}$, CDC, and CMA. With pan-CDEC responsibility the Committee's chair would be the military Chief of Staff of CDEC. $^{47}$

The Officer Development Board also recommended the formation of an Educational Council based largely on the preexisting Canadian Military Colleges' Council; the new body would be chaired by the Deputy for Education. Its primary function would be to make recommendations about the programs to be implemented within the system. Its duties would include advising the Commander on issues to take before the CDS and Armed Forces Council (the senior military policy body), including "Coordination of courses of the CDC, CMC and CMA to ensure uniformity and sequence in the development process." 48

It was evident that Rowley had made a fairly conscious decision to set up CDEC's working philosophy along university lines, but with key roles for members of the profession of arms. To have a military chair for a committee concerned with faculty advancement and a civilian chair presiding over a body mandated to assess the officer corps' education requirements must have been seen as radical. Finally, the ODB recommended that the existing RMC Advisory Board be expanded to include responsibility for those academic programs offered under the Defence College. The Advisory Board would report to the Minister of National Defence, thus ensuring that the elected head

Ibid., 339.

Ibid., 339-40.

Ibid., 340-41.

Ibid., 341-42. 
of the Department of National Defence would have both feedback on the activities of the military's professional development system and an independent source of advice on education matters in general. This weaving together of responsibilities could have been seen as a system of checks and balances, but another more positive interpretation would be to view this as a strengthening process contributing to a common understanding of the role of professional education and the mechanisms to ensure its success. The structure was then and remains today unique among NATO nations, where the rule generally is to split academically oriented military colleges, which may operate like a university, from staff and war colleges, which until recently have provided professional education without academic credit or recognition.

DESPITE Allard's endorsement of the Report in March 1969, and his overall support for the ODB's proposals, the Canadian Defence Education Centre was not activated. Instead, a similar construct - the Canadian Defence Education Establishments (CDEE) - was created on 1 January 1970. Rather than having his teaching units located with his headquarters, Milroy, now appointed as Commander CDEE following Rowley's departure on reaching compulsory retirement age, would control the existing organizations from offices in Ottawa. According to Milroy the shift from CDEC to CDEE was made based on his own recommendation in view of the realpolitik of events in Ottawa. The defence establishment in the city and the nation was shrinking and timing was therefore ill-suited for the creation of a new and highly visible organization in the capital. As well, after a meeting with defence minister Leo Cadieux, he came away with a clear understanding of the power of the three existing military colleges. He had also developed his own appreciation of the value of keeping the three colleges open for regional visibility and cadet recruiting. ${ }^{49}$

The CDEC concept had come under attack, largely from the military colleges, almost as soon as Allard signed the report. Professor Richard Preston, a historian at the Royal Military College at the time of the Report, has documented the demise of the Board's vision from that college's perspective. Co-location 
and amalgamation hit a raw nerve with RMC advocates, who were soon arguing that the ODB had miscalculated costs. Preston attributed the problems to the ODB's development of an "ideal system... without regard to its cost." ${ }^{50}$ He noted that in his memoirs Allard blamed these problems on Rowley's deputy, Brigadier General B.J. Guimond, who had added the military colleges' mandate and budget to the CDEC when there had been no authority to do so. ${ }^{51}$ And yet the ODB's terms of reference called for exactly the comprehensive scheme it had devised: the Board's first task dealt with entry programs and its fourth remit involved the creation of the necessary control and co-ordination mechanisms for officer development. ${ }^{52}$ In any case Allard's criticism is perhaps moot since he had approved the report and its recommendations when, if anyone, he had had the authority to reject the proposal. The ODB had presented a plan for a coordinated and effective officer professional development system that included a better control over the various colleges and schools. There were costs involved, but there were also benefits. As Motiuk recalls, opponents to the plan were disingenuous in presenting their costing concerns, adding in operating costs for fifteen years, costs that would have been borne by any professional development system. ${ }^{53}$

Preston also argued that Prime Minister Trudeau's rearticulation of defence priorities, one month after the ODB Report was issued, cast doubt upon the Board's defence policy premises. He felt that the authors' focus on "Pearsonian internationalism made their report seem out of line with Trudeau's concern for Canada and North America." 54 Preston claimed that this caused the Report to lose "political credibility." Surely, though, such shifts in defence policy and force

50 Richard A. Preston, To Serve Canada: A History of the Royal Military College Since the Second World War (Ottawa: University of Ottawa Press, 1991), 102-3. Only since the mid-1990s has RMC taken a wider view of professional development. Preston's RMC-centric view of the ODB offers an accurate example of a protectionist approach, taken by both staff and alumni, which was very much in evidence in the late 1960s and early 1970s. When a program was instituted to give degrees to non-commissioned members studying at RMC it was necessary to create a new Canadian Military College degree in order to maintain the traditions of the RMC program. Interview with Dean A.J. Barrett, Jan. 2002.

51 General Jean V. Allard (with Serge Bernier), The Memoirs of General Jean V. Allard (Vancouver: University of British Columbia Press, 1988), 269; Preston, To Serve Canada, 103.

52 ODB Report, Vol. 1: Annex A, 1.

53 Interview with LCol. (retd.) L. Motiuk, Jan. 2001.

54 Preston, To Serve Canada, 105. 
employment were just the sorts of things that the Board had been thinking of when it had articulated the need for long-term integrity and continuity. ${ }^{55}$ Just because the defence policy of the nation changed, one should not have assumed, not that the CDEC concept was wrong, but rather that the focus of some of the educational programs would need review and perhaps adjustment. To suggest, as Preston appeared to imply, that the professional development system would need to be revised every time the government changed its security and defence priorities seems unimaginable. As Larry Motiuk commented at the time, in a Canadian Institute of International Affairs paper: "Courses could be instituted or dropped as the occasion warranted without changing the basic role of the establishment." 56

Despite the participation on the ODB by Dean Tom Hutchinson of RMC, his faculty colleagues felt some discomfort with the proposed Canadian Military College. ${ }^{57}$ One can only presume that their unease would have included everything from possible loss of seniority to the problems of family relocation. The RMC commandant, Commodore Hayes, considered reporting to a two-star commander to be a step down from his previous letter of appointment from the CDS. ${ }^{58}$ Much of 1970 was spent in discussion and debate as to what committees and boards were needed to regulate the policies and practices of RMC. $^{59}$ While Preston attributed the decision not to co-locate the three military colleges, and the subsequent abandonment of a year-round undergraduate program, to financial considerations, the decision would surely have been influenced to some degree by this political wrangling. Indeed, Motiuk has indicated that detractors were hacking away at the Report from the moment it was tabled. ${ }^{60}$

It would appear from Allard's memoirs and Preston's commentary that the proposed amalgamation of the existing military colleges within the CDEC structure, with the resulting loss of identity and physical presence, had been too much for the faculty and, one suspects, the alumni to bear. As institutions go,

\footnotetext{
55 ODB Report, Vol. 3: 313.

56 Laurence Motiuk, "The Officer Corps and the Future," in Canadian Military Professionalism: The Search for Identity, ed. R.B. Byers and Colin S. Gray, Wellesley Paper 2, Feb. 1973 (Toronto: Canadian Institute of International Affairs, 1973), 44.

57 Preston, To Serve Canada, 106.

58 Ibid., 107.

59 Ibid., 107-9.

60 Interview with LCol. (retd.) L. Motiuk, Jan. 2001.
} 
and particularly institutions such as RMC with long and proud histories, opposition to such a radical proposal was to be expected.

DESPITE CRITICISM of the ODB concept and the less-thanoptimal structure, the CDEE was soon able to champion some issues. The expansion of facilities at the three military colleges in conjunction with the shift to the degreed officer corps concept of the ODB was described in an article in Canadian Defence Quarterly by RMC's Director of Cadets at the end of $1971 .^{61}$ The new post-commissioning Professional Development System was the subject of another article by National Defence Headquarters' Director of Education. The system would consist of a Junior Staff Course, a Junior Command and Staff Course (Land), and a Command and Staff Course. Those destined for senior appointments would have an opportunity to attend the National Defence College; however, unlike Rowley's model there would be no Advanced Military Studies Course. The author explained the philosophy behind the programs: they would impart both knowledge of the profession and at the same time the skills needed to properly employ that knowledge "research, organized thinking, problem solving and the process of expressing [one's thoughts] orally or in writing." The system's purpose was "thus clearly revealed. It is to broaden progressively a career officer's perception of his place in the military profession and the professions' role in society."62 From this one can see that, while not having the physically centralized and rationalized organization recommended by Rowley, there at least existed a coherent series of courses and programs approximating the ODB's vision, the whole under the control of one commander. Compared to the pre-unification mix of training and education philosophies, this new system was a significant improvement.

The Canadian Defence Quarterly also provided a venue for criticism. If there was a common focus to the contrary

61 LCol. R.A. White, “Change and Fealty to Tradition: Today's Royal Military College of Canada,” Canadian Defence Quarterly 1, 3 (Winter 1971): 41.

62 Colonel A.P. Wills, “A New Professional Development System for Canadian Forces Officers,” Canadian Defence Quarterly 3, 2 (Autumn 1973): 40-41. While Col. Wills is identified as Director of Education in the article he was likely actually Director of Professional Education and Development, an organization which replaced CDEE, as shall be described below. 
commentary that began to appear as early as 1971 it was one of concern for the profession of arms and for the lack of professional development policy: what sorts of courses, for whom, when, why? Indeed the second issue of the resurrected journal included two such articles written by young officers. ${ }^{63}$ Expressing his concern that the profession was out of touch with the nation, Captain P.S. Bury stated: "It is significant that in John Porter's The Vertical Mosaic [1965], considered a definitive study of modern Canadian society, there is no mention of the Services. It appears that the serviceman's status in the eyes of his masters, the public, is not necessarily low, but rather irrelevant." ${ }^{\prime 4}$ Ironically, the CDEC, embodying the ODB philosophy of preparing officers to understand socioeconomic trends and overseeing courses covering such topics as elements of national power, formulation of defence policy, and Canadian internal issues, ${ }^{65}$ would have addressed this problem head on. A second article attacked the Post-Graduate Training program. How could the military keep young officers with Master's degrees interested when job satisfaction and working conditions conspired to have them head for the professions associated with their graduate qualifications? Surely, argued the author, himself a retired Captain, it would be better to invest this advanced education in those mid-career officers who intended making the Forces their profession. Acknowledging the ODB concept of post-graduate education and proposals for master's credits based on professional education, the author nonetheless left the clear impression that he was unhappy with much of the post-graduate philosophy. ${ }^{6}$

By the end of 1974 five other articles had appeared criticizing various aspects of professional education. Junior officers, one said, required some form of assistance in undertaking mandated professional self-improvement. ${ }^{67}$ There were concerns that pre-commissioning officer production had lost its way, with RMC becoming nothing more than a university

63 Canadian Defence Quarterly had stopped publishing in 1938 and only became active again in 1971.

64 Captain P.S. Bury, "The Profession of Arms in Canada Today: An Infantry Officer's View,” Canadian Defence Quarterly 1, 2 (Autumn 1971): 46.

65 ODB Report, Vol. 2: 206, 253, 260.

66 Captain (retd.) Robin McNeil, "The Post Graduate as an Officer: Is there, must there be, a conflict?" Canadian Defence Quarterly 1, 2 (Autumn 1971): 50-52.

67 Captain J.O. Dendy, "Needed: Direction, Support Recognition of Professional Self Improvement," Canadian Defence Quarterly 1, 3 (Winter 1971): 42-45. 
giving whatever degrees suited the professorial cadre, regardless of the Canadian Forces' requirements. ${ }^{68}$ There was no professional development between the basic officer course and the Staff School; officers needed something "to remedy a worsening situation." "69 A final pair of commentaries zeroed in on the Regular Officer Training Plan, suggesting that the sequencing of education, operational training, and initial operational employment was all wrong. ${ }^{70}$

Clearly there were some disgruntled "students" who might have been happier with the CDEC concept. Undoubtedly even the ODB model would have suffered some growing pains in the early years, but with one commander and an effective organization that concentrated decisions on policy, plans, and operations firmly within a small group of experienced military and civilian educators, one can reasonably assume that satisfaction among the officer corps would have been more prevalent. That was certainly what the ODB's vision of "one officer factory" had been intended to foster.

Concerns from "customers" and infighting among "stakeholders" would not seem completely unpredictable: the Canadian military was in the middle of a massive institutional reorganization. This said, one is repeatedly struck by the fact that a well-mandated, strategically supported CDEC could at least have faced these problems squarely with the knowledge that it was working with a good plan and the authority and accountability to get on with the necessary changes. But by the end of 1972 there was neither a CDEC nor a CDEE. Instead, a Directorate of Professional Education and Development (DPED), run by a colonel, had been created to handle the national level administration of the military and staff colleges. This staff organization was to report through two intermediaries, the Director General Recruiting Education and Training and the Chief of Personnel Development, to the Assistant Deputy Minister for Personnel - one-, two-, and three-star officers respectively. The latter would "command and control" the various institutions, chair the Educational Council, and have

68 Lieutenant-Commander J.G.M. Smith, "What is Wrong with Pre-commissioning Officer Education," Canadian Defence Quarterly 2, 1 (Summer 1972): 11.

69 Captain M.N.G. Hutton, "On Professional Advancement: Training for Junior Officers," Canadian Defence Quarterly 3, 1 (Summer 1973): 58.

70 Commander F.H. Hope, "What's Wrong with the ROTP," Canadian Defence Quarterly 4, 2 (Autumn 1974): 48-49. 
overall responsibility for education and professional development policy. ${ }^{71}$ Despite this apparent top-down approach, in practice many of the policy initiatives either came from staff officers or originated in the colleges. ${ }^{72}$ This approach meant that busy senior officers, burdened with high volumes of minutiae, were not well positioned to deal with professional development issues. Moreover, these generals, caught in staff rather than line appointments, often found themselves without the necessary authority to make decisions and issue direction. ${ }^{73}$ This less-thanoptimal system, as it existed in 1972, was to remain relatively intact until the mid-1990s.

One is left to wonder whether more could have been done at the time to ensure the success of officer professional development. If one accepts the tumultuous reorganization of the services into one unified force, the desires of politicians and senior commanders to downsize the military footprint in Ottawa, the aspirations of the military colleges to continue their traditional mandates and programs, and the general lack of support for the Canadian Forces by government in the early 1970 s, then the system that was created and operated seems, perhaps, the best that might have been hoped for.

DURING THE 1990s and continuing into the new millenium, the Canadian Forces and Canadian governments have sought to deal with a number of crises and challenges to the officer corps. Precipitated largely by the peace dividend and the errors of Somalia, the CF first reviewed officer professional development issues through studies and boards ${ }^{74}$ and then by the direction of the Minister of National Defence. ${ }^{75}$ Plans began to take form in the 1996-98 period with changes to senior officer education,

\footnotetext{
71 Preston, To Serve Canada, 123.

72 The author worked in the neighbouring Directorate of Language Training from 1989 to 1991 as the section head responsible for language training policies, plans, and operations.

73 Interview with LGen. (retd.) F.R. Sutherland, Feb. 2001.

74 Canada, Department of National Defence, Report of the Officer Development Review Board (Ottawa: DND, 1995). The Chair of the ODRB was Lieutenant-General Robert Morton. Canada, Department of National Defence, The Officer Professional Development Working Group Final Report (Toronto: DND, 1996). The Chair of the Working Group was Commodore K.A. Nason.

75 Hon. M. Douglas Young. Report to the Prime Minister on the Leadership and Management of the Canadian Forces, 25 Mar. 1997,

http://www.forces.gc.ca/eng/min/reports/PM/mnd.60.html; accessed 2 July 2002.
} 
including two new courses commencing in 1998 (the Advanced Military Studies Course and the National Security Studies Course). ${ }^{76}$ A proposal for major reforms to officer entry schemes, the Enhanced Leadership Model, calling for more leadership and values inculcation and a mandatory balanced arts and science undergraduate program for those entering RMC, was tabled in $1999 .{ }^{77}$ The first RMC class to enter under this scheme graduated in 2004. Associated with this proposal was the institution of a degreed-officer corps policy. ${ }^{78}$ Most recently, steps have also been taken to allow master's level credits for the senior courses, and RMC offered a professional master's degree (Master of Defence Studies) in conjunction with the Command and Staff Course for the first time in 2001 . $^{79}$

But these reforms were the result of a number of initiatives coming from a variety of agencies. There were many, and some might argue too many, players in these improvements. Indeed, one of the criticisms levelled by the Minister's Monitoring Committee on Change, an organization established by the Minister in 1997 to confirm the implementation of directed change strategies, was that there was no firm guidance or policy in place to ensure an effective overall system. ${ }^{80}$

In response to these criticisms and recommendations, work began in 2001 that led to the establishment of the Canadian Defence Academy in 2002. Like the CDEC proposal, the Academy has one military college and one professional college, the Royal Military College and the Canadian Forces College respectively. Like the CDEC vision, the Commander of the

76 Two new courses were introduced for colonels and generals (and naval equivalents) at the Canadian Forces College in Toronto: the Advanced Military Studies Course and the National Security Studies Course. At the same time the College made changes to the longrunning Command and Staff Course. The author participated in all of these reforms. 77 The proposal, known as the Enhanced Leadership Model (ELM), called for all new officer candidates to complete approximately six months of various military selection, acculturation, and language-training activities before embarking on existing professional development, training, or education programs.

78 Young, Report to the Prime Minister. Recommendation 10 states: "Change policies beginning in 1997 to make a university degree a prerequisite to commissioning as an officer, with the only exceptions to be made for those commissioned from the ranks"; http://www.forces.gc.ca/eng/min/reports/PM/mnd.60.html; accessed 2 July 2002.

79 RMC and the Canadian Forces College obtained approval from the Ontario Council of Graduate Studies in June 2001 and 39 members of the Command and Staff Course received their Master of Defence Study Degrees in June 2002.

80 Canada, Department of National Defence, Minister's Monitoring Committee on Change in the Department of National Defence and the Canadian Forces Interim Report - 1999 (Ottawa: DND, 1999), 1-3. The Chair of the Monitoring Committee was the Hon. John Fraser. 
CDA is the Force's "champion for lifelong learning." And like the CDEC proposal, CDA has the task of co-ordinating all common professional development and academic education across the Canadian Forces. Like CDEE, the CDA has not succeeded in grouping all its resources into one location; however, it has brought its major campuses to within a day's drive of its headquarters in Kingston. And like Allard's vision for excellence in education and professional development, the CDA has the full support of the current Chief of Defence Staff, General Ray Henault, who, acknowledging the seminal part played by Rowley, stated in the CDA preliminary Charter: "Professional development is at the heart of the Profession of Arms. The CDA will play a vital role in the reform and transformation of our professional standards and competencies." ${ }^{81}$

BY PROPOSING a unique defence education command, Rowley sought to focus attention on the fundamental importance of officer development in ensuring the success of the profession of arms and by extension the Canadian Forces. He knew that only by creating a self-sustaining interest in professional development could the Canadian officer corps maintain itself as a capable and credible military profession. Most of the constituent elements of Rowley's programs were instituted and yet the profession faltered, if only briefly, during the mid-1990s. While an explanation for this result cannot be categorically demonstrated, what may have been missing was a sufficient authority and responsibility to ensure that the education and professional development programs remained relevant and that the knowledge, skills and values that Rowley believed were so important to the officer corps would be safeguarded and nurtured through professional education. Now, more than thirty years after the ODB completed its work, the Canadian Forces is returning to Rowley's philosophies and structures in creating the Canadian Defence Academy. Going beyond Rowley's focus on officers and recognizing the intellectual challenges of the modern battlefield, the CDA will champion learning for all

81 Canada, Department of National Defence, A Charter for the Canadian Defence Academy. At the time of writing only a draft document has been developed. The changes of Ministers in the spring of 2002 and again in late 2003 have delayed the final approval of the charter. 
members of the Canadian Forces. Yet while the circumstances and the student body may have evolved, Rowley's central message remains as important today as it was then:

It matters little whether the Forces have their present manpower strength and financial budget, or half of them or double them; without a properly educated, effectively trained, professional officer corps the Forces would, in the future, be doomed to, at the best, mediocrity; at the worst disaster. $^{82}$

82 ODB Report, Vol. 1: iv. Taken from the Foreword signed by General Allard. 